\title{
Raiding pastoral livelihoods: motives and effects of violent conflict in north-western Kenya
}

\author{
Janpeter Schilling ${ }^{1,2^{*}}$, Francis EO Opiyo ${ }^{3,4}$ and Jürgen Scheffran ${ }^{1}$
}

\author{
* Correspondence: jschilling@ \\ colgate.edu \\ ${ }^{1}$ Research Group Climate Change \\ and Security, Institute of Geography, \\ University of Hamburg, KlimaCampus \\ Hamburg, Grindelberg, 7, 20144, \\ Hamburg, Germany \\ ${ }^{2}$ Department of Geography, Colgate \\ University, 13 Oak Drive, Hamilton, \\ New York 13346, USA \\ Full list of author information is \\ available at the end of the article
}

\begin{abstract}
Conflicts related to livestock raiding are not new phenomena in many pastoral societies in the Horn of Africa. Traditionally, various pastoral communities use raiding as a cultural practice for restocking of herds, especially after periods of drought or outbreaks of diseases. However, in recent years, livestock raiding has become more frequent, violent and destructive.

This paper elucidates, first, the motives behind the current livestock raiding, and second, it analyses how conflict affects livelihoods of pastoral communities. Between 2008 and 2011, focus group discussions and interviews were carried out with 376 members of the Turkana and Pokot communities and key informants.

The study findings suggest that hunger and drought impacting on availability and access of resources are critical raiding motives among the Turkana, while increasing wealth and payment of dowry are the most important motives for the Pokot community. Violent conflict poses a significant threat to pastoral livelihoods which are already under pressure from recurrent drought, diseases and political marginalisation. The direct impact of violent raiding is felt in terms of loss of human life and property, reduction in livestock numbers, limited access to water and pasture resources and forced migration. Indirectly, violent conflicts create a strong and omnipresent perception of insecurity which results in ineffective resource utilisation, reduced mobility, food insecurity and closure of markets and schools. These factors combined undermine adaptation strategies and pastoralism altogether. Hence, a framework of conflict mitigation is needed which addresses the specific raiding motives of each group.
\end{abstract}

Keywords: Livestock, Violent conflict, Raiding, Pastoralism, Pokot, Turkana, Kenya

\section{Background}

Pastoralists reside in over 21 countries across the African continent. Many of these communities are affected by conflicts, while the Sahel region and East Africa show sustained levels of inter-pastoral violent conflicts with associated potential impacts on their livelihoods (Bevan 2007). Pastoralism is a major economic production strategy in which people raise herds of animals, mostly in arid and semi-arid lands (ASALs). ASALs cover about $80 \%$ of Kenya's landmass and support about a third of the country's human population and 70\% of the national livestock herd. An estimated 13 million cattle, 25 million goats, 14.9 million sheep, 1.7 million donkeys and 2.9 million camels are found in Kenya's ASALs (KNBS 2010). The highest livestock populations are held by the Turkana and Pokot pastoralists of north-western Kenya (GoK 2010).

\section{严 Springer}

(c) 2012 Schilling et al.; licensee Springer. This is an Open Access article distributed under the terms of the Creative Commons Attribution License (http://creativecommons.org/licenses/by/2.0), which permits unrestricted use, distribution, and reproduction in any medium, provided the original work is properly cited. 
Pastoralism contributes approximately $12 \%$ to the country's gross domestic product (FAO 2005), with the livestock sector providing an estimated $90 \%$ of all employment opportunities and more than 95\% of household incomes in ASALs (Kaimba et al. 2011).

Pastoralism practised by the majority of Turkana and Pokot ethnic groups is mainly nomadic transhumance, which is characterised by risk-spreading and flexible mechanisms, such as mobility, communal land ownership, large and diverse herd sizes, and herd separation and splitting (Opiyo et al. 2011). The livestock types kept by the Turkana and Pokot to manage and spread risk include cattle (zebu), camels, goats, sheep and donkeys. Livestock possession plays multiple social, economic and religious roles in pastoral livelihoods, such as providing a regular source of food in the form of milk, meat and blood for household members, cash income to pay for cereals, education, health care and other services. In pastoral communities, livestock is also essential for payment of dowry, compensation of injured parties during raids, symbol of prosperity and prestige, store of wealth and security against drought, disease and other calamities. Livestock is therefore a fundamental form of pastoral capital, besides functioning as a means of production, storage, transport and transfer of food and wealth (Behnke 2008).

In north-western Kenya, pastoral communities have a long history of conflicts. In the broadest sense, conflict can be defined here forceful interaction as a result of opposing views. As pastoralism revolves around livestock, the conflicts are predominantly about livestock and its related productive assets - water, land and pasture. These resources closely tie conflicts to the violent theft of livestock, referred to as raiding, which is both a contributing factor and an articulation of conflict. On the one hand, raiding leads to distrust between communities which is a prerequisite of conflict (Mwangi 2006). On the other hand, communities use raiding to articulate their hostility toward enemy communities (Eaton 2008). Traditionally, livestock raiding often involved small-scale manageable violence and theft of the best livestock or replacement of animals lost during periods of droughts or diseases. Loss of human lives was rare, and when this occurred, compensation in the form of livestock was paid to the victims or their families in case of death (Mkutu 2008). The Turkana and Pokot pastoralist communities have used raiding and violence to restock herds, expand grazing lands, gain access to water and pasture resources and increase social status for more than 9,000 years (Eaton 2008; Moru 2010). However, in recent years, due to the proliferation of modern small arms, commercialisation of livestock raiding, dispute over land tenure rights, banditry and predation, the cultural practice has become a widespread, sophisticated, more violent, and destructive activity among pastoral communities in northern Kenya (Mkutu 2008; Kumssa et al. 2009; Leff 2009; Mahmoud 2011; Njiru 2012; Omolo 2010). The proliferation of modern automatic weapons is well documented as having had a negative effect on the scale and impact of armed violence in pastoral communities (Mirzeler and Young 2000; Mkutu 2006). In addition, commercialised livestock raiding in which wealthy businessmen, politicians, traders and local people pursue economic objectives has interfered with pastoral livelihoods and contributed to conflicts among pastoral communities (Kaimba et al. 2011; Eaton 2010; Mkutu 2010).

Although violent conflict is one of the greatest challenges that the Turkana and Pokot pastoralists have to deal with, its influence on pastoral livelihoods in north-western Kenya has not been adequately documented. There have been studies (Kaimba et al. 2011; Mkutu 2010) to assess the drivers and mitigation mechanism for the resource-based conflicts in pastoral areas, but it has hardly been possible to analyse the motives and challenges posed 
by violent conflicts because of the complexity and multidimensional character of the conflicts in the region. This study pursues two objectives. First, an agent-based approach is used to explore why the Turkana and Pokot pastoral communities engage in violent conflicts with each other. In conjunction with this question, a typology of raiding and a brief discussion of the role of different community members in raiding is presented. Second, the study's objective is to structure and analyse the complex effects of violent conflicts on pastoral livelihoods. Specifically, the study exemplifies the effects of violent conflict on resource access and utilisation, impacts on livestock markets, trade and inter-communal relations between the Turkana and Pokot communities of north-western Kenya.

\section{Methods}

\section{Study area}

The study was predominantly conducted in the southern rangelands of Turkana and northern parts of West Pokot County in north-western Kenya (Figure 1). As part of

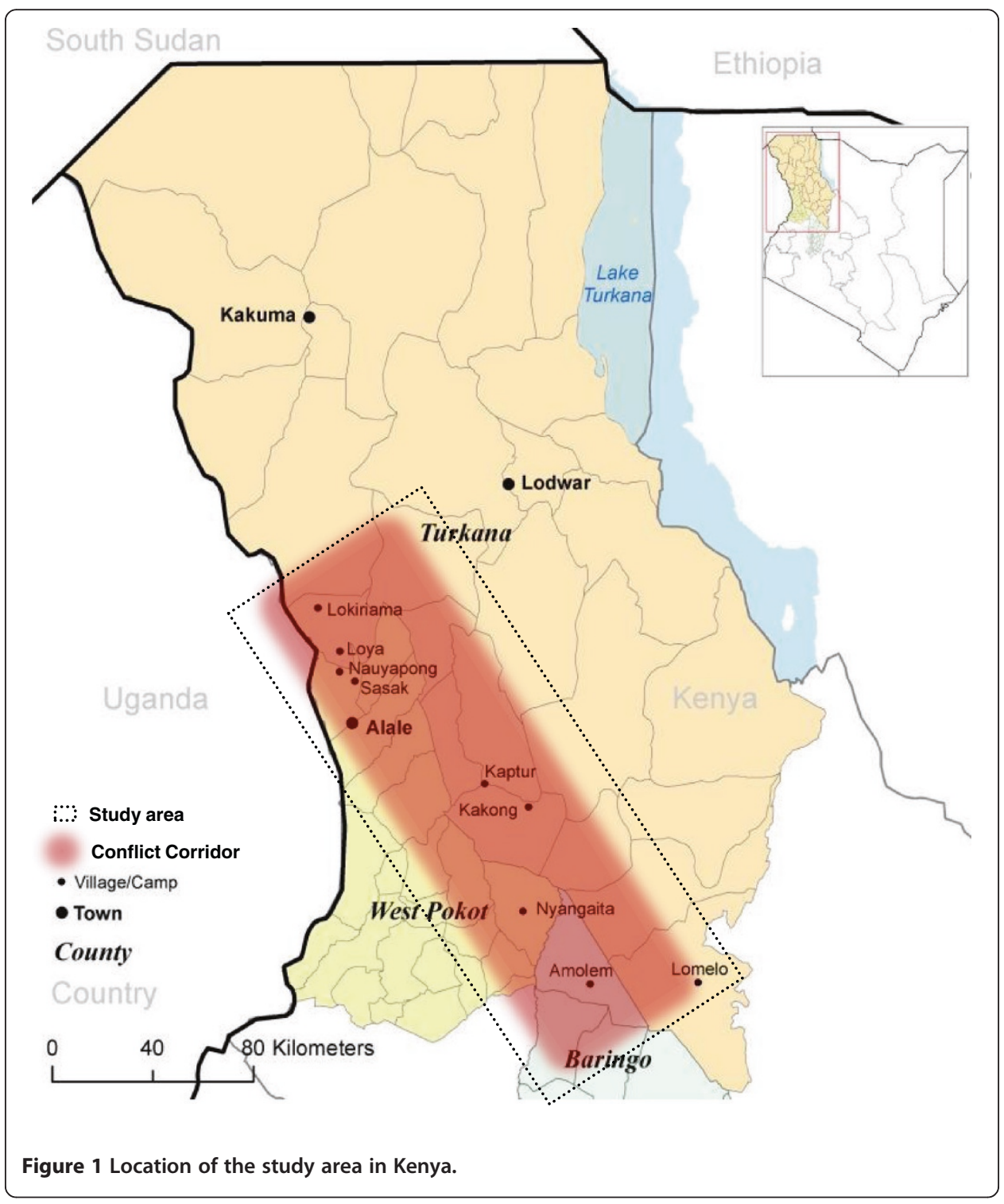


Kenya's Rift Valley, the region is characterised by a highly variable and erratic rainfall regime which is bimodal in pattern. The short rains occur between October and November; the long rains, between March and May. The erratic rainfall regime is manifested in floods and droughts which are frequently recorded in the region (Huho et al. 2011; Morton 2006). The mean annual temperature ranges between a minimum of $26^{\circ} \mathrm{C}$ and a maximum of $38^{\circ} \mathrm{C}$, with high evapotranspiration rates (GoK 2008).

The vegetation mainly consists of scattered Acacia bush and herbaceous plant species. The density of the woody plants such as Acacia reficiens and Acacia mellifera increases on hilly ground (Mureithi and Opiyo 2010). Several ephemeral rivers commonly referred to as laghas crisscross the region. Besides the two semipermanent rivers, Turkwel and Kerio, Lake Turkana is the only permanent source of water in north-western Kenya. In addition to the limited and varying natural resources, the Turkana and Pokot region has experienced significant political marginalisation which has led to a lack of basic services such as education, road infrastructure and health services (GoK 2007; McSherry and Brass 2008). Subsistence nomadic pastoralism is the main source of livelihood for the Turkana and Pokot communities in the study area. However, some small-scale irrigation farming is practised along the rivers Turkwel and Kerio.

\section{Data collection}

Data collection for this study was carried out between September 2008 and December 2011. Interviews and discussions were conducted with a total of 376 persons consisting of leaders (chiefs, elders) and other members (women, pastoralists, youth, raiders) of the communities. The communities shown in Figure 1 were chosen to cover the Turkana and Pokot perspective to an equal degree on both sides of the administrative border. The interviewees within each community were selected using a systematic random sampling based on ranking. While samples of all community subgroups were interviewed, raiders and pastoralists were given higher ranks as these two subgroups are the ones most directly involved in the raiding. The interviews with the raiders were conducted anonymously and without voice recording as the raiders were asked about their own raiding experience and involvement. A raider was defined as a person who participates actively in livestock raids. Some of the raiders were also pastoralists, referring to persons who own and herd livestock as their main livelihood.

Close to the same number of community members were interviewed in Turkana and West Pokot. For instance, they were asked how secure they feel in their area. While this question entails a certain degree of subjectivity as the definition of security varies from individual to individual, the question was instrumental to understand the effects of the conflicts as discussed in the 'Results and discussions' section. In addition to the community interviews, key informants were interviewed to get a more distant view on raiding motives, conflict trend lines and conflict effects on rural livelihoods. Someone was considered a key informant when he or she had a record of theoretical knowledge or extended practical experience in the fields of conflict and raiding in the region. Examples for key informants include administrative officials (e.g. district commissioners), nongovernmental organisation (NGO) representatives (e.g. Practical Action) and religious leaders (e.g. priests). The key informants were interviewed in the study area and in towns such as Lodwar, Nakuru and Nairobi. 
A social survey, focus group discussions (FGDs) and interviews were carried out within community clusters in southern Turkana, northern and eastern parts of West Pokot and northern Baringo (Figure 1). Further, participating and non-participating observations were conducted to complement the data from interviews and FGDs.

Conflict data were analysed using Excel (Microsoft, Redmond, WA, USA) and the statistical package 19.0 for social sciences (SPSS, Chicago, IL, USA). The conflict records were taken from the local NGO Turkana Pastoralist Development Organization (TUPADO) who records raiding incidents in Turkana from 2000 up to 2011 (TUPADO 2011) and from the governmental institution Conflict Early Warning and Response Mechanism (CEWARN) which covers raiding incidents in both Turkana and West Pokot region since 2002. The TUPADO register contains information such as date and location of the raid, number and type of people injured or killed and raided animals as well as the number and origin of the raiders. Names of raiders are however not listed.

\section{Theoretical framework}

The theoretical framework is based on an agent-based approach which understands community action as an outcome of a group of agents following common decision and behavioural rules (Scheffran et al. 2012). As the rules are not limited to optimising utility but also include social norms and risk assessment, the agent-based approach is helpful to explore the complex relationship between the Turkana and the Pokot (see Baregu (2011) for examples of similar approaches). The raiders of each group are used as agents because the interviews indicated that the raiders are the ones essentially making the decision on whether to conduct a raid or not. Their decision is however as much influenced by other community members as the raiders' decision determines the prosperity of the community (see 'Results and discussions' section for details).

The relationship between the Turkana and the Pokot can take two general forms: conflict or cooperation (Figure 2). Conflict in this study refers to violent conflict which is understood as forceful interaction as a result of opposing views about pasture, water and livestock. Cooperation on the other hand relates to the peaceful sharing of resources and a state in which differences are reconciled peacefully. Whether the communities choose a conflicting or cooperative path depends on the motivation and capability of communities, respectively raiders to realise a certain path. If one element is missing or underdeveloped, the path cannot be chosen.

The motivation is mainly determined by weighing the expected gains and losses of certain courses of action. Livestock raiders, for example, weigh the likelihood of capturing a significant number of livestock against the likelihood of getting shot, wounded or arrested. For an actor to be motivated to engage in cooperation, the benefits of the cooperation, for example, in the form of inter-community reciprocal grazing agreements,

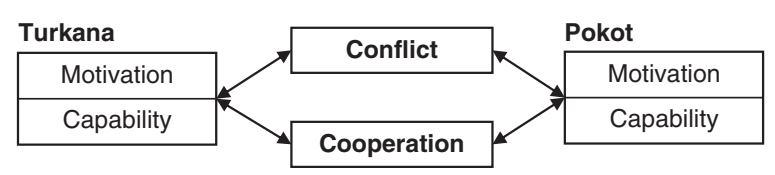

Figure 2 Theoretical framework for conflicting and cooperative pathways between Turkana and Pokot. 
have to outweigh the benefits from livestock raiding. While raiding gives raiders an opportunity to realise immediate livestock gains, the raiding also increases the risk of retaliation by the raided community. Cooperation, on the other hand, improves the security of the cooperating communities, but the resource gains in the form of access to water and pasture are mostly realised in the mid to long term.

Capability is usually defined as the ability to execute a certain course of action (Scheffran et al. 2012). In the context of raiding, the capability is mainly determined by the availability of resources, men, weapons, ammunition, skills and information about the target such as the location of herds, types of livestock and level of protection. The capability to choose a cooperative path mainly depends on whether a community is able to establish reliable agreements with the neighbouring community.

In theory, both Turkana and Pokot communities have the choice between investing into resource sharing (cooperative path) or pursuing livestock raiding and the destruction of the competitor's capabilities (conflicting path). Yet, in practice, Figure 2 shows that if one community chooses the conflict path, the other actor is almost forced to take this path as well to avoid disadvantages. The overall benefit from mutual cooperation theoretically exceeds the one of a conflicting relationship as no resources are wasted for destructive purposes.

\section{Results and discussion}

\section{Types of livestock raiding}

The Turkana and Pokot ethnic communities have been on a conflicting path for so many decades that respondents were unable to recall a year when they went without raiding and conflicts. In both communities, the majority of chiefs, elders, women, pastoralists, youth and raiders stated that the conflict with the other group has escalated in recent years. This finding is in line with other studies which have reported an increased conflict between the Turkana and the Pokot as well as other communities in north-western Kenya (Mkutu 2008; Omolo 2010; de Vries et al. 2006; McCabe 2004; UNDP 2011). Regardless of the ethnic community, the study findings show that the majority of people going for raids are male youth and younger men mostly below the age of 30. Based on the interviews with the communities, three types of livestock raids can be identified according to their number of participating raiders. First, in highly organised 'mass raids', several hundreds to even thousands of raiders attack a neighbouring community. Second, in 'adakar ${ }^{\text {'a }}$ raids, several dozens and occasionally up to a few hundred raiders from nearby villages come together to raid one village or kraal of a rivalling community. The third type of raids is the smallest with mostly a handful to less than 15 participating raiders. The targets of the later raids are usually small, unprotected kraals or a group of animals which is only accompanied by one pastoralist or herd boy.

The majority of the people interviewed suggest that there has been a shift from mass and adakar raids to smaller but more frequent raids. This perception is reflected in the data as the average number of raiders per raid in Turkana decreased from 48 raiders in 2006 to 28 raiders in 2009 (TUPADO 2011). The shift is likely to be the result of two developments: (1) improved communication infrastructure which reduces the attractiveness of mid- and larger-sized raids and (2) commercialisation which increases the attractiveness of smaller raids. The improved coverage of mobile phone networks, especially in Pokot, significantly increases the chances of the targeted community and administrative authorities 
to notice and prepare for the planned raid. This in turn decreases the motivation of raiders to participate in a raid as the risk of getting shot by the targeted community or arrested by the administrative authorities is increased. Additionally, the required capability of mid- and larger-sized raids is high. Not only does a community have to organise and coordinate a larger number of participants, it also has to know where and when a significant herd can be found and attacked. Smaller raids, in contrast, require a shorter organisation period and hence attract less attention. Here, the risk of getting arrested is smaller. The motivation of raiders to engage in smaller raids is further increased by the development of commercialisation. Krätli and Swift (2003) define commercialisation as 'an aspect of the wider integration of pastoralists within a market economy'. This form of raiding is undertaken with the explicit intention of selling livestock for immediate profit instead of restocking own herds (Mkutu 2010). Commercialised raiding is facilitated by improved access to markets, rising demand for meat as part of strong growth of urban populations and improved road infrastructure reaching pastoral regions (Eaton 2010).

\section{Motives of livestock raiding}

In this study, motives of raiding not only refer to general developments that contribute to raiding, but also to reasons why individuals engage in raiding. Besides the aforementioned development of commercialisation (Krätli and Swift 2003; Buchanan-Smith and Lind 2005), other studies have documented a variety of different motives to explain the phenomenon of livestock raiding among pastoralists in Kenya. The spectrum ranges from poverty (Omolo 2010), payment of dowry and accumulation of general wealth (Bollig 1993; Hendrickson et al. 1998) to retaliation (Eaton 2008), tribal-based politics (McCabe 2004), institutional set-ups (Adano et al. 2012), availability of small arms (Mkutu 2006; Gray et al. 2003) and climate change-related (Adano et al. 2012; Campbell et al. 2009; Schilling et al. 2012; Witsenburg and Adano 2009) and unrelated resource degradation (Meier et al. 2007). Most of these studies agree that competition and scarcity of resources in the form of water, pasture, land resources and livestock assets play a key role in the conflicts between pastoral groups.

The present study generally confirms the importance of livestock and natural resources as important elements of the conflict. However, the present study also shows that the conflicting parties engage in the same conflict for different reasons. In Turkana, the majority of raiders indicated hunger and drought as their primary and secondary motives for engaging in livestock raiding (Table 1). In Pokot, payment of dowry and accumulation of wealth were the strongest motives while the expansion of territory summarised as 'land' in Table 1 was still given by $25 \%$ of the Pokot raiders as a primary motive. This asymmetry in raiding motives reflects the different resource availabilities in the research area the time of the interviews (September and November 2011). West Pokot had received above average rainfall, while in Turkana, the long rains between March and May had completely failed.

Table 1 Motives for raiding as stated by Turkana and Pokot raiders

\begin{tabular}{lllllll}
\hline Motive & & Hunger & Wealth & Dowry & Land & Drought \\
\hline Primary & Turkana & $78 \%$ & $22 \%$ & & & \\
& Pokot & & $25 \%$ & $50 \%$ & $25 \%$ & \\
\multirow{2}{*}{ Secondary } & Turkana & & $33 \%$ & $22 \%$ & & $44 \%$ \\
& Pokot & $25 \%$ & $75 \%$ & & & \\
\hline
\end{tabular}


Consequently, the Pokot side was rich in pasture, water and animals, while the communities on the Turkana side relied almost entirely on food aid as they had lost most of their livestock during the extended dry period. Hence, for the Turkana, the raiding is more a question of survival than for the Pokot. Apart from the differences in motives, the raiders on both sides are well aware of the risks and potential gains of their raids. One Turkana raider summarised the rationality behind the raiding with the words 'I bring [livestock] or I die'. During the interview period with the communities, several interviewees on both sides reported minor raids in which, however, no or few people got hurt.

While the differences in raiding motives were confirmed in the interviews with other community members and in FGDs, they are not representative for the entire county of Turkana or West Pokot as the research area only covers part of the two counties and the sample of raiders was limited to 21 . However, taking into account that raiders are a delicate group to interview, the results help to complete the picture, drawn by the remaining interviews and data analysis. In Pokot, a connection between the accumulation of wealth and commercialised raiding was more pronounced in the interviews with government officials and experts, while raiders denied that they sell a large portion of the captured livestock. In Turkana, several representatives of the government and NGO respondents stated that the expansion of the Pokot territory into the plains of Turkana and vice versa is one of the central drivers of violent conflicts. Several key informants suggested that this process is politically driven while few indications to support this notion were found during interviews with the communities. Generally, this is compounded by a tendency to view pastoral rangelands as both uninhabited and under-productive (Schilling and Remling 2011). Regardless of the degree of political instrumentalisation and marginalisation, the demarcation of political administrative boundaries between the Pokot and Turkana grazing range was considered a contributing conflict driver by several key informants, particularly district commissioners and representatives of NGOs.

In summary, the strongest motives for raiding were drought and poverty on the Turkana side. On the Pokot side, payment of dowry and accumulation of wealth, and to a lesser extent, expansion of territory were found to be the strongest motives. Some key informants linked these motives to commercialisation trends of raiding and political incitement. Beyond the motives behind the raiding, the community interviews provided insight into the role of other community members in raiding.

\section{Role of elders, women and chiefs in livestock raiding}

As Turkana and Pokot raiders are part of the respective community, their decision on whether to raid or not is influenced by other community members, particularly elders, women and chiefs. However, their role in raiding is ambivalent. In the short term, the community usually gets a share of the acquired livestock, especially after a successful adakar or mass raid (see previous section). In the long run, however, the community suffers from the negative effects of the conflict (see following section).

The interview findings on the role of the elders are particularly contrasting. On the one hand, the majority of Turkana and Pokot raiders report that the elders encourage or even assist their raids with blessings and information (for example, where to find the enemy's livestock). Further, several raiders stated that the elders receive a share of the livestock, sometimes even 'the biggest bull'. On the other hand, most elders claim to 
discourage the raiding. Some acknowledged that they occasionally benefit from the raids or the raiders 'just go on their own', as one woman phrased it. One focus group discussion with both raiders and elders in Lokiriama was instrumental to match these seemingly opposing views. During times of peace with the Pokot, the elders discourage the youth to raid the Pokot, while during times of conflict, the elders hardly ever refuse a pre-raid blessing.

Women are found to have an influence on the raiding activity of their men. They either encourage their men and prepare meals after a successful raid, or they play a discouraging role, for example, by expressing their fear to lose their man. The village chiefs are in a difficult position. On the one hand, they are the representation of the national government on the ground and hence have to prevent or sanction raiding; on the other hand, they understand why the community engages in raiding.

The only group exclusively profiting from the raiding is the group of traders and businessmen which gets access to inexpensive livestock which they can sell for a higher price in urban centres such as Lodwar, Nairobi or Moroto in Uganda (see also Eaton 2010). The traders are usually not part of the communities and hence do not experience the effects of the raiding and conflicts.

\section{Effects of conflict on pastoral livelihoods}

Conflicts and livestock raiding affect the well-being of pastoral communities in various direct and indirect ways. This section attempts to structure and analyse the complex effects by supplementing the results of the present study with findings of previous research. The top of Figure 3 lists the motives of raiding as identified earlier in the article. The effects (most direct ones shown in bold) of the raiding and conflict are discussed in detail below.

\section{Loss of human lives}

The most direct effect of raiding on human well-being is the loss of lives and injuries caused during the raids. In Turkana alone, TUPADO recorded 592 raid-related deaths

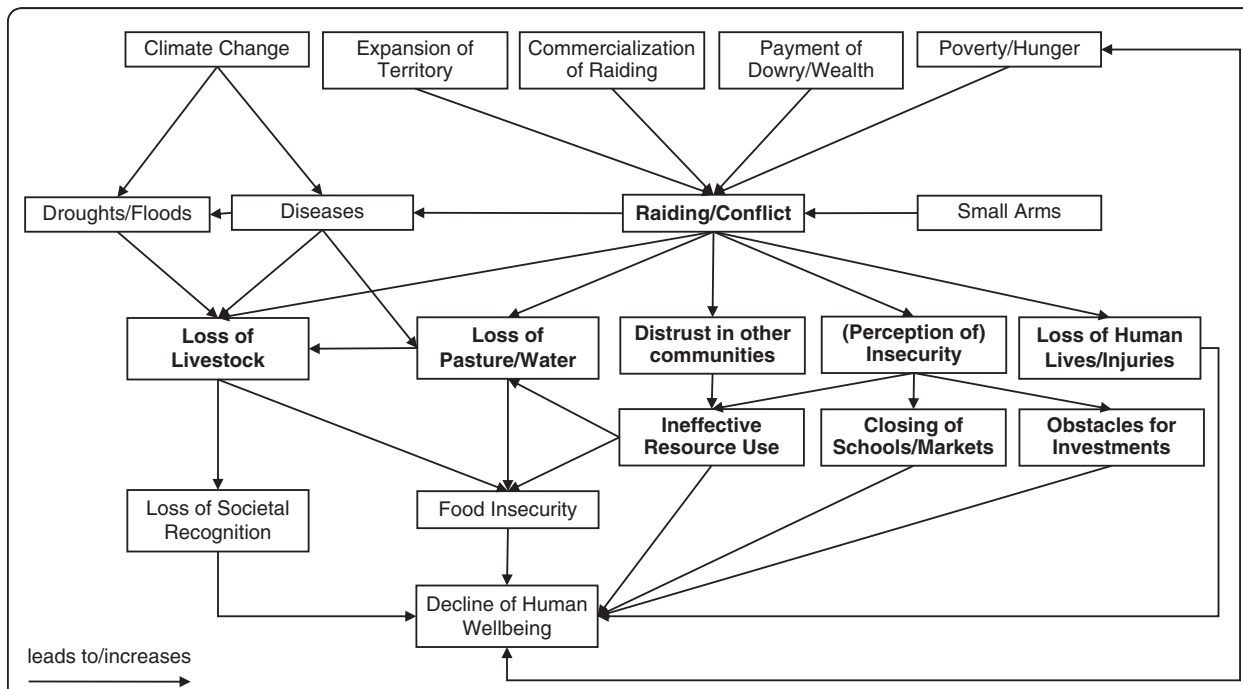

Figure 3 Motives and effects of raiding and conflict in Turkana and Pokot. 


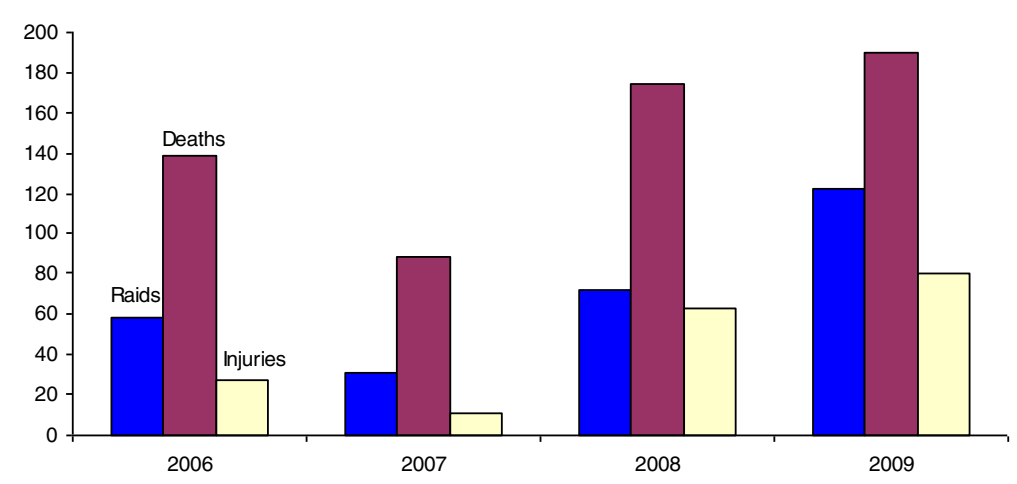

Figure 4 Number of raids, deaths and injuries during raids in Turkana between 2006 and 2009. Based on TUPADO (2011)

between 2006 and 2009 (Figure 4). For Turkana and Pokot county combined, the governmental institution CEWARN reports a number of conflict-related deaths of 640 in 2009 alone (CEWARN 2010). In Figure 4, the high number of deaths in relation to the number of injuries indicates that the availability of small arms has made raiding more deadly. Raiders reported in interviews that wounded raiding fellows, especially when unable to walk, are left behind and often shoot themselves to 'escape' punishment by the attacked group. Injured and killed raiders reduce the labour available for livestock herding and community protection. As raiders are almost exclusively young men, the raiding does not only affect the community in short terms, but also reduces the future prosperity of the community. However, not only raiders fall victim to the conflicts. Even government officials are not spared as the killing of the assistant chief of Lokiriama, James Longorid Achuman shows. He was shot on 18 December 2011 together with his moped driver on the way from Lokiriama to Moroto, Uganda. As no money or valuables were stolen and the footprints of the attackers led to Uganda, the chief of Lokiriama, police forces and an NGO representative independently suggested that it was a revenge attack by the Pokot or Tepeth who recently lost several community members in a raid by the Turkana. Beyond the physical impacts of the conflicts on humans, Pike et al. (2010) have documented negative psychological consequences, for example, traumas.

\section{Effects on livestock numbers}

The effects of conflict and raiding on livestock numbers can be both direct and indirect. Indirectly, raiding contributes to loss of livestock through the spread of diseases (Bett et al. 2009; Oloya et al. 2006). The direct effect of raiding can be both positive (for the raiding community) and negative (for the raided community). From the raider's perspective, raiding can appear to be an effective and direct tool to increase their own herd, at the cost of those who are raided. If two or a few groups in a confined area reciprocally raid each other without selling livestock to outside actors, the total number of livestock may remain fairly the same.

However, the development of commercialisation (see previous discussion) has extracted large numbers from the traditional raiding circle, despite efforts of security forces to curb the trading of stolen livestock (Eaton 2010). Turkana and Pokot experienced a net loss of livestock of more than 90,000 animals due to raids between 2006 and 2009 (CEWARN 2010). This number has to be treated with caution as raided communities tend 
to report higher numbers hoping to receive higher compensations (Eaton 2008). Yet, the number points to the dimension of losses that some communities experience. During this research, $75 \%$ of the pastoralists and raiders reported to have lost livestock, partly due to raids and drought-related incidences. A reduction in livestock population, even by small numbers, is critical especially for the pastoralists who depend on livestock for income and food security. Similarly, it was reported that losing livestock also goes hand-in-hand with the loss of societal recognition. Without livestock, young men cannot marry as they are unable to pay dowry. Elders, functioning as communal judges, are suffering from loss of livestock, too. During focus group discussions in Turkana, elders complained that the youth does not respect them anymore. A raider in Pokot North referring to the youth and elders summarised that 'without cattle, you are useless' (see also McCabe 2004). While in both communities, the loss of livestock due to raiding was a strong theme in the interviews, the accusations of the Turkana toward the Pokot undermining their livelihood were stronger. One woman in Lobei complained during an interview: 'the Pokot, they took our cattle, they took everything.' She continued to explain that she and her family are now completely relying on food aid. Particularly for women and children, the loss of livestock whether caused by raiding, drought or disease can result in lack of nutrition (Pike et al. 2010; Pike and Williams 2006). Hence, hunger can be both an outcome and a motive of conflict as the interviews with the raiders in Turkana have shown (Table 1).

\section{Loss of homes and resources}

The conflict between the Turkana and the Pokot is mostly about livestock raiding which usually takes place in some distance to the villages. However, occasionally, bigger kraals and even entire villages are attacked. Based on the interviews and the TUPADO data, it is possible to define an approximate corridor where the conflicts between the Turkana and the Pokot are most intense with respect to the level of perceived insecurity and number of reported raiding incidences and attacked homesteads (Figure 1). For example, 20 homesteads were reported to be looted and destroyed between 2008 and 2011 in and around Kaptur alone. In October 2011, the village of Nauyapong was found abandoned due to insecurity caused by Turkana raiders. Only the school staff and the students had remained; they were constantly protected by the nearby military camp. The rest of the Nauyapong community had moved south to more secure areas in and around Alale (Figure 1). While the abandonment of entire settlements is a rare case, the loss of pasture and water points is a common phenomenon in conflict-prone rangelands of north-western Kenya. Eriksen and Lind (2009) point to the formation of loose grazing associations to expand territory. In these so called 'arumrum,' 'up to a few hundred households' (Eriksen and Lind 2009:830) come together to take over larger areas with pasture. Watering points are a source of conflict particularly during dry periods. In Lokiriama, several exchanges of gunfire were witnessed between the Turkana and the Pokot who were trying to access the borehole at night. In Lasak and Nauyapong, on the other hand, it was reported that the Turkana have recently started to steal maize and beehives because of hunger. Besides the direct loss of resources, the conflicts cause effects which indirectly reduce human well-being through insecurity.

\section{Insecurity and its subsequent effects}

In both communities, there is an omnipresent perception of pronounced insecurity (Figure 5). In southern Turkana, 96\% of the people interviewed felt insecure or highly 


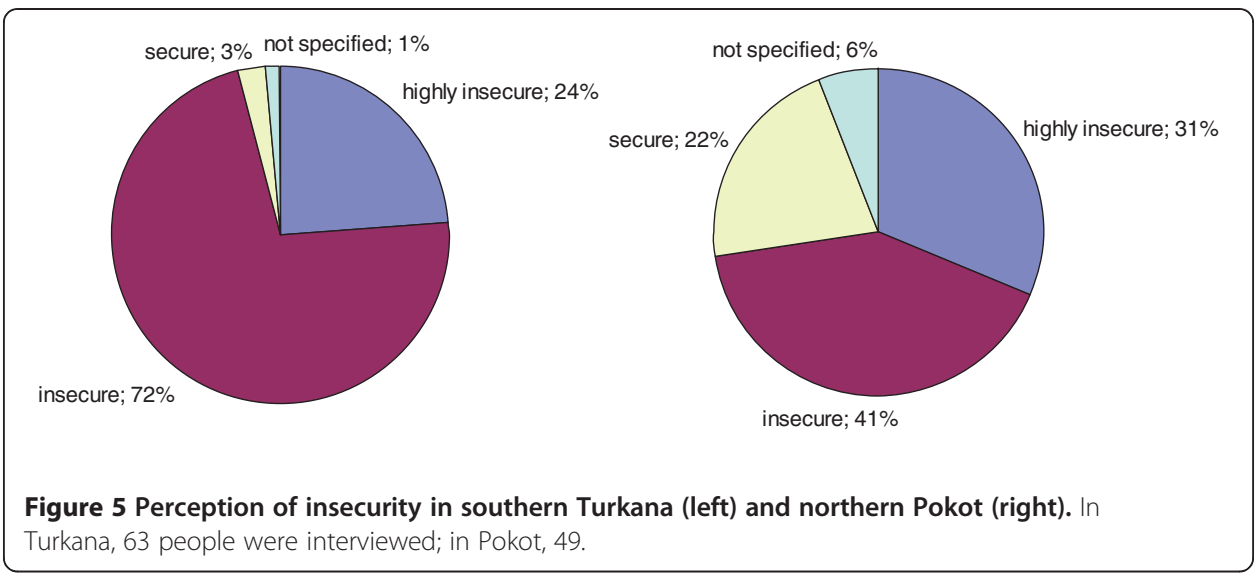

insecure. When asked about the reason for the insecurity, the interviewees in both communities gave these replies: raids, conflicts or the enemy. The larger percentage of interviewees reporting a secure feeling in Pokot can be explained by the fact that almost $40 \%$ of the interviews were from Alale which is a bigger town with stronger governmental presence and hence higher security. Insecurity and the perception of it have three major effects, which in turn reduce human well-being: first, inefficient resource utilisation, second, closing of markets and schools and third, posing an obstacle for investments. Earlier estimates by Morton (2001) show that between 15\% and 21\% of north-western rangelands have become more or less inaccessible to Turkana and Pokot pastoralists due to enduring inter-community ethnic tensions. In this study, interviews as well as the TUPADO data suggest that the border region between Turkana and Pokot, including Lokiriama, Sasak, Amolem and Lomelo, have become increasingly inaccessible (Figure 1). Similarly, it was observed that the rangelands south of Loya, located between the Turkana plains and the highlands of Pokot, were rich in pasture. Yet, neither of the two groups was accessing the area because of insecurity. The insecurity is further increased by highway robbery of bandits who take advantage of the power vacuum. In addition, the underutilization of pasture bares the risk of encroachment of certain species which deplete the pasture or make it inaccessible (Opiyo et al. 2011; Bollig 1990; Huho et al. 2009). Unused boreholes can become a source of livestock poisoning (Mbaria et al. 2005). Along river Turkwel and Kerio, 78\% of the pastoralists are forced by conflicts to migrate with their livestock to the neighbouring water sources in Karamoja of Uganda, while 10\% are confined within the few safe riverbanks that remain. This concentration of people and livestock increases the likelihood of overuse of resources and poses a potential source of new conflict. The majority of respondents reported that they are afraid to move freely when conflicts are ongoing in the study area. Similarly, Kaimba et al. (2011) find that livestock raiding interrupts the mobility which is an integral part of pastoralism in the region. Women in Lokiriama and in the nearby villages Lobei and Urum reported that they have reduced the picking of wild berries because they are afraid to get killed or raped. This shows how insecurity undermines adaptation to drought as the picking of wild berries was reported to be an important strategy to adapt to water and pasture scarcity.

The effects of insecurity on pastoral livelihoods go beyond a reduction of food resources. It was observed that livestock markets in Lokiriama and Loya are not used 
because of insecurity. The lack of secure markets limits the ability of the pastoralists to sell livestock prior to or during dry periods and hence contributes to food insecurity (Barrett et al. 2003; Juma 2010; Speranza 2010). During the three years of this study, Turkana reported that options to sell livestock to traders were limited as they were afraid of attacks on their way to Kitale or Nairobi. Influx of grains and manufactured goods into Pokot and Turkana was also reported to be negatively affected by insecurity. The school in Lokiriama was temporarily closed when conflicts intensified, as teachers reported. Bullet holes in classroom buildings were still visible. The head teacher in Lobei expressed hope that the school grounds would soon be fenced off to prevent Pokot from getting close to the pupils.

Insecurity does not only interrupt education; it also poses an obstacle for development. Today, Turkana is the poorest and most marginalised county in relatively rich Kenya. For example, the construction of the road between Lokiriama and Lorengipi was stopped as the security of the construction workers could not be assured.

Beyond the physical effects, insecurity negatively affects the inter-communal relations. Community members of both Pokot and Turkana have expressed strong negative feelings and distrust towards the other group. The distrust decreases the motivation and the capability of the communities to choose a cooperative path which is a prerequisite for peaceful and effective resources sharing (Eriksen and Lind 2009). Inter-communal relations particularly deteriorate when raids include the rape or abduction of women. This practice could increase the incentive for parents to marry off their daughters early into the 'safe hands' of a husband (see Little et al. 2009). Another response to such hostile attacks is retaliation which further fuels the conflict (Eaton 2008).

Overall, the results suggest that the asymmetry found in the motives of raiding does not translate into major differences in the (perceived) effects of the conflicts. The destructiveness of the conflicts was stressed in both groups.

\section{Conclusions and implications}

The aim of this study was to understand the motives behind the raiding and to analyse the effects of the conflict on pastoral livelihoods. The major conflict motives are asymmetric. On the Turkana side, the reduction in pasture, water and livestock has made raiding the only survival alternative other than relying on food aid. Consequently, hunger and drought were identified as the main motives for raiding. On the Pokot side where pasture and water were available at the time of the research, the accumulation of wealth, payment of dowry and, to a lesser extent, the expansion of territory are found to be the strongest motives for raiding.

Among the most direct effects of the raiding are loss of human lives, reduced number of livestock as well as reduced access to water, pasture and even loss of homes. In addition, the conflicts lead to distrust in other communities and a strong omnipresent perception of insecurity which entails several and partly interconnected subsequent effects. These effects include ineffective resource use, reduced mobility, closing of markets and schools and obstacles for investments. In combination with droughts, diseases, small arms and social, political and economic marginalisation, the effects of raiding pose a significant threat for pastoral livelihoods. In fact, one could argue that the conflicts are 'raiding pastoral livelihoods'.

Against this background, there is a need for effective conflict mitigation that breaks the cycle of violence, retaliation and impoverishment. To move from the conflicting to 
a cooperative path, one could start by addressing the capability of the actors. In theory, disarmed groups cannot cause as much harm as armed groups. However, as governmental disarmament efforts of the past were selective and poorly coordinated, they predominantly failed, partly aggravating conflicts between communities (Mkutu 2008; Wepundi et al.). Given the high availability of small arms in the region, it is more promising to address the motivation of the actors by decreasing the attractiveness of raiding and increasing the attractiveness of non-violent alternatives that increase the capabilities in cooperative activities. Hence, increasing the level of development as suggested by Kaimba et al. (2011) is theoretically a useful instrument to decrease raiding as it provides the youth with opportunities to engage in alternative livelihoods, for example, paid labour. However, investments in formal education are also problematic as, for instance, young men who attend school are unable to look after livestock at the same time. The lack of labour is likely to further decrease the survivability of traditional pastoralism. Hence, development alone will not be purely beneficial to pastoral livelihoods, especially because conflict is a major obstacle to investment as observed in this study. Instead, any investments in development in north-western Kenya need to be embedded into a framework of conflict mitigation which offers incentives for both conflict parties to simultaneously leave the violent conflict path and to invest resources into cooperation. Livelihood and development incentives are needed to address the specific raiding motives of each group.

\section{Endnotes}

aAdakar' can be understood as 'cluster of often related families that pursue similar socio-economic activities including grazing management' (Bett et al. 2009)

Competing interests

The authors declare that they have no competing interests.

\section{Authors' contributions}

JPS and FO collected the data and drafted most parts of the manuscript. JS drafted the theoretical framework and revised the remaining parts. All authors read and approved the final manuscript.

\section{Authors' information}

JPS is a Postdoctoral Fellow in the Department of Geography at Colgate University and a Research Associate in the research group Climate Change and Security at the University of Hamburg. FO is a Disaster Risk Reduction Manager at International Rescue Committee, Nairobi (Kenya) and a doctoral candidate at the Department of Land Resource Management and Agricultural Technology at the University of Nairobi (Kenya). JS is a Professor of Geography at the University of Hamburg and the leader of the research group Climate Change and Security.

\section{Acknowledgements}

The researchers are grateful to the Turkana and Pokot communities who volunteered the information during this study. We thank TUPADO for letting us use the raiding register. Special thanks go to Raphael Locham from Reconcile/ Practical Action, Tony Locham and Theresa Marc for their assistance. This work is supported through the Cluster of Excellence 'Integrated Climate System Analysis and Prediction - CliSAP' (EXC177), University of Hamburg, funded by the German Science Foundation (DFG). The German Academic Exchange Service (DAAD) partially founded the field research. The publication of the article was financially supported by the Research Council of Colgate University.

\footnotetext{
Author details

'Research Group Climate Change and Security, Institute of Geography, University of Hamburg, KlimaCampus Hamburg, Grindelberg, 7, 20144, Hamburg, Germany. ²Department of Geography, Colgate University, 13 Oak Drive, Hamilton, New York 13346, USA. ${ }^{3}$ International Rescue Committee, 5th Ngong Avenue, IKM Place, Nairobi, Kenya. ${ }^{4}$ Department of Land Resource Management and Agricultural Technology, University of Nairobi, Utalii Lane, Nairobi, Kenya.
}

Received: 11 June 2012 Accepted: 4 October 2012 Published: 3 December 2012

References

Adano, WR, T Dietz, K Witsenburg, and F Zaal. 2012. Climate change, violent conflict and local institutions in Kenya's drylands. Journal of Peace Research 49(1): 65-80.

Baregu, M (ed.). 2011. Understanding obstacles to peace - actors, interests, and strategies in Africa's Great Lakes region Kampala: Fountain. 
Barrett, CB, F Chabari, D Bailey, PD Little, and DL Coppock. 2003. Livestock pricing in the Northern Kenyan Rangelands. Journal of African Economies. 12(2): 127-155.

Behnke, RH. 2008. The economic contribution of pastoralism: case studies from the horn of Africa and Southern Africa. Nomadic Peoples 12(1): 45-79.

Bett, B, C Jost, R Allport, and J Mariner. 2009. Using participatory epidemiological techniques to estimate the relative incidence and impact on livelihoods of livestock diseases amongst nomadic pastoralists in Turkana South District, Kenya. Preventive Veterinary Medicine 90(34): 194-203.

Bevan, J. 2007. Between a rock and a hard place: armed violence in African pastoral communities. Nairobi: UNDP.

Bollig, M. 1990. Ethnic conflicts in North West Kenya: Pokot-Turkana raiding 1969-1984. Zeitschrift für Ethnologie 115: 73-90.

Bollig, M. 1993. Intra-and interethnic conflict in Northwest Kenya: a multicausal analysis of conflict behaviour. Anthropos 88(1): 176-184.

Buchanan-Smith, M, and J Lind. 2005. Armed violence and poverty in Northern Kenya - a case study for the Armed Violence and Poverty Initiative. Bradford: Centre for International Cooperation and Security/Bradford University.

Campbell, I, S Dalrymple, C Rob, and A Crawford. 2009. Climate change and conflict - lessons from community conservancies in northern Kenya. Winnipeg: International Institute for Sustainable Development.

CEWARN. 2010. CEWARN country updates: September-December 2009. CEWARN (Conflict Early Warning and Response Mechanism): Addis Ababa

de Vries, D, P Leslie, and J McCabe. 2006. Livestock acquisitions dynamics in nomadic pastoralist herd demography: a case study among Ngisonyoka herders of South Turkana, Kenya. Human Ecology 34(1): 1-25.

Eaton, D. 2008. Violence, revenge and the history of cattle raiding along the Kenya-Uganda border. Halifax: Dalhousie University.

Eaton, D. 2010. The rise of the 'traider': the commercialization of raiding in Karamoja. Nomadic Peoples 14(2): 106-122.

Eriksen, S, and J Lind. 2009. Adaptation as a political process: adjusting to drought and conflict in Kenya's Drylands. Environmental Management 43(5): 817-835.

FAO. 2005. Livestock sector brief. Kenya. http://www.fao.org/ag/againfo/resources/en/publications/sector_briefs/sb_KEN.pdf. Accessed 22 February 2012

GoK. 2007. National policy for the sustainable development of arid and semi arid lands. Nairobi: Government of Kenya.

GoK. 2008. Arid lands resource management project Turkana: annual progress report. http://www.aridland.go.ke/ arid_annual_reports/arid_annual_07-08/turkana_07-08.pdf. Accessed 27 June 2011.

GoK. 2010. National climate change response strategy. Nairobi: Government Press.

Gray, S, M Sundal, B Wiebusch, MA Little, PW Leslie, and IL Pike. 2003. Cattle raiding, cultural survival, and adaptability of East African pastoralists. Current Anthropology 44(S5): S3-S30.

Hendrickson, D, J Armon, and R Mearns. 1998. The changing nature of conflict and famine vulnerability: the case of livestock raiding in Turkana District, Kenya. Disasters 22(3): 185-199.

Huho, JM, JKW Ngaira, and HO Ogindo. 2009. Climate change and pastoral economy in Kenya: a blinking future. Acta Geologica Sinica - English Edition 83(5): 1017-1023.

Huho, JM, JKW Ngaira, and HO Ogindo. 2011. Living with drought: the case of the Maasai pastoralists of northern Kenya. Educational Research 2(1): 779-789.

Juma, M. 2010. Security and regional cooperation in Africa: how can we make Africa's security architecture fit for the new challenges? In Heinrich Böll Foundation (ed) Climate change, resources, migration - securing Africa in an uncertain climate. Cape Town, pp 16-25.

Kaimba, G, B Njehia, and A Guliye. 2011. Effects of cattle rustling and household characteristics on migration decisions and herd size amongst pastoralists in Baringo District, Kenya. Pastoralism: Research, Policy and Practice 1(1): 1-18.

KNBS. 2010. 2009 Kenya population and housing census. Nairobi: KNBS.

Krätli, S, and J Swift. 2003. Understanding and managing pastoral conflict in Kenya. Sussex: University of Sussex.

Kumssa, A, JF Jones, and JH Williams. 2009. Conflict and human security in the North Rift and North Eastern Kenya. International Journal of Social Economics 36(10): 1008-1020.

Leff, J. 2009. Pastoralists at war: violence and security in the Kenya-Sudan-Uganda border region. International Journal of Conflict and Violence 3(9): 188-203.

Little, PD, AA Aboud, and C Lenachuru. 2009. Can formal education reduce risks for drought-prone pastoralists?: a case study from Baringo District, Kenya. Human Organization 68(2): 154-165.

Mahmoud, HA. 2011. Conflict and constraints to peace among pastoralists in Northern Kenya. In Understanding obstacles to peace - actors, interests, and strategies in Africa's Great Lakes region, ed. M Baregu, 146-168. Kampala: Fountain.

Mbaria, JM, RW Munenge, AN Njuguna, JL Orre, and D Dabasso. 2005. Occurrence of a severe acute livestock poisoning by borehole water in Marsabit District, Kenya: a case study. Kenya Veterinarian 28: 16-19.

McCabe, JT. 2004. Cattle bring us to our enemies: Turkana ecology, politics, and raiding in a disequilibrium system. Ann Arbor: University of Michigan Press.

McSherry, B, and JN Brass. 2008. The political economy of pro-poor livestock policy reform in Kenya. Nairobi: IGAD.

Meier, P, D Bond, and J Bond. 2007. Environmental influences on pastoral conflict in the Horn of Africa. Political Geography 26(6): 716-735.

Mirzeler, M, and C Young. 2000. Pastoral politics in the northeast periphery in Uganda: AK-47 as change agent. Journal of Modern African Studies 38(3): 407-429.

Mkutu, KA. 2006. Small arms and light weapons among pastoral groups in the Kenya-Uganda border area. African Affairs 106(422): 47-70.

Mkutu, KA. 2008. Guns and governance in the Rift Valley - pastoralist conflict and small arms. Bloomington: Indiana University Press.

Mkutu, KA. 2010. Complexities of livestock raiding in Karamoja. Nomadic Peoples 14(2): 87-105.

Morton, J (ed.). 2001. Pastoralism, drought and planning: lessons from Northern Kenya and elsewhere. Natural Resources Institute, DFID: Greenwich.

Morton, J. 2006. Policy options paper: community based drought management for the pastoral livestock sector in Sub-Saharan Africa. http://www.fao.org/fileadmin/templates/lead/pdf/e-conf_06-10_drought.pdf. Accessed 23 February 2012. 
Moru, ERJ. 2010. Adaptation to climate variability among the dry land population in Kenya: a case study of the Turkana pastoralists. Wageningen: Wageningen University.

Mureithi SM and Opiyo FEO. 2010. Resource use planning under climate change: Experience from Turkana and Pokot pastoralists of Northwestern Kenya. In Proceedings at 2nd International Conference on Climate, Sustainability and Development in Semi Arid Regions. 16 - 20 August 2010, Fortaleaza, Ceara, Brazil.

Mwangi, OG. 2006. Kenya: conflict in the 'Badlands': the Turbi Massacre in Marsabit District. Review of African Political Economy 33(107): 81-91.

Njiru, BN. 2012. Climate change, resource competition, and conflict amongst pastoral communities in Kenya. In Climate change, human security and violent conflict: challenges for societal stability, ed. J Scheffran, M Brzoska, HG Brauch, PM Link, and J Schilling, 513-527. Berlin: Springer.

Oloya, J, J Opuda-Asibo, B Djønne, J Muma, G Matope, R Kazwala, and E Skjerve. 2006. Responses to tuberculin among zebu cattle in the transhumance regions of Karamoja and Nakasongola district of Uganda. Tropical Animal Health and Production 38(4): 275-283.

Omolo, NA. 2010. Gender and climate change-induced conflict in pastoral communities: case study of Turkana in northwestern Kenya. African Journal on Conflict Resolution 10(2): 81-102.

Opiyo, FEO, SM Mureithi, and RK Ngugi. 2011. The influence of water availability on pastoralist's resource use in Kitui and Mwingi districts of Kenya. Journal of Human Ecology 35(1): 43-52.

Pike, IL, and SR Williams. 2006. Incorporating psychosocial health into biocultural models: preliminary findings from Turkana women of Kenya. American Journal of Human Biology 18(6): 729-740.

Pike, IL, B Straight, M Oesterle, C Hilton, and A Lanyasunya. 2010. Documenting the health consequences of endemic warfare in three pastoralist communities of northern Kenya: a conceptual framework. Social Science \& Medicine 70(1): 45-52.

Scheffran, J, PM Link, and J Schilling. 2012. Theories and models of climate-security interaction: framework and application to a climate hot spot in North Africa. In Climate change, human security and violent conflict: challenges for societal stability, ed. J Scheffran, M Brzoska, HG Brauch, PM Link, and J Schilling, 91-131. Berlin: Springer.

Schilling, J, and E Remling. 2011. Local adaptation and national climate change policy in Kenya: discrepancies, options, and the way forward. Munich: Paper presented at the Summer Academy on Social Vulnerability: Climate Change and Fragile States: Rethinking Adaptation.

Schilling, J, M Akuno, J Scheffran, and T Weinzierl. 2012. On raids and relations: climate change, pastoral conflict and adaptation in Northwestern Kenya (under review). In Climate change and conflict: where to for conflict sensitive climate adaptation in Africa? ed. S Bronkhorst and U Bob. Durban: Human Sciences Research Council.

Speranza, Cl. 2010. Drought coping and adaptation strategies: understanding adaptations to climate change in agropastoral livestock production in Makueni District, Kenya. European Journal of Development Research 22(5): 623-642.

TUPADO. 2011. Turkana Pastoralist Organisation incident register 2000-2010. Lodwar: TUPADO. Unpublished

UNDP. 2011. Drought and potential conflict scenarios in northern Kenya and other arid lands: a situational report. Nairobi: UNDP.

Wepundi, M, J Ndung'u, and S Rynn. 2011. Lessons from the frontiers - civilian disarmament in Kenya and Uganda. Nairobi: Saferworld.

Witsenburg, KM, and WR Adano. 2009. Of rain and raids: violent livestock raiding in Northern Kenya. Civil Wars 11(4): 514-538

doi:10.1186/2041-7136-2-25

Cite this article as: Schilling et al: Raiding pastoral livelihoods: motives and effects of violent conflict in northwestern Kenya. Pastoralism: Research, Policy and Practice 2012 2:25.

\section{Submit your manuscript to a SpringerOpen ${ }^{\circ}$ journal and benefit from:}

- Convenient online submission

Rigorous peer review

- Immediate publication on acceptance

- Open access: articles freely available online

- High visibility within the field

- Retaining the copyright to your article

Submit your next manuscript at $\boldsymbol{\sim}$ springeropen.com 